\title{
MAINTENANCE RESEARCH OF A HORIZONTAL RIBBON MIXER
}

\section{BADANIA EKSPLOATACYJNE MIESZALNIKA WSTĘGOWEGO POZIOMEGO}

\begin{abstract}
During operation of the mixing device there are many technical problems affecting technological processes implemented with their involvement. In order to improve the efficiency of feeding with mixed feed, mixed feed should be prepared from quality mixes. Despite the widespread use of various types of mixers, their operation is not sufficiently understood, therefore the study of the effects of the design and technological parameters on mix quality is an urgent task. Experimental studies were carried out in the livestock farming mechanisation laboratory of the North-East Scientific Research Institute of Agriculture of the Federal State Budgetary Scientific Institution. The article presents the research of the feed mix composed of barley and rice as a base mix, and feed mix of peas used as a reference component.
\end{abstract}

Keywords: energy consumption, feed mixing, maintenance, mathematical modelling, mixing parameters.

\begin{abstract}
Podczas eksploatacji urządzenia mieszającego występuje wiele czynników technicznych wpływających na procesy technologiczne. W celu poprawienia przyswajalności mieszanek paszowych, powinny one być wytworzone na mieszalnikach zapewniajacych jednorodność $i$ wysoka jakość mieszanek. Pomimo powszechnego stosowania różnych rodzajów mieszalników, procesy w nich zachodzace nie sa do końca rozpoznane, a zatem badanie wpływu konstrukcji i parametrów technicznych na jakość mieszanki jest zagadnieniem stale aktualnym. Badania doświadczalne zostaty przeprowadzone w Laboratorium Mechanizacji Produkcji Zwierzęcej w Strefowym Instytucie Naukowo-Badawczym Rolnictwa Pótnocno-Wschodniego Rosyjskiej Akademii Nauk. W artykule przedstawiono badania mieszanki paszy złożonej z jęczmienia i ryżu jako mieszanki bazowej oraz mieszanki paszowej grochu wykorzystywanej jako komponent odniesienia.
\end{abstract}

Stowa kluczowe: zużycie energii, mieszanie pasz, konserwacja, modelowanie matematyczne, parametry mieszania.

\section{Introduction}

Technological progress is the counterpart to the growing demand for novel machines and devices that should be characterised by high reliability, functionality, and an extended time of operation in extreme conditions [9], as well as the achievement of the assumed accuracy of machining [16]. Exploitation of structural elements of machines and technical devices usually significantly differs from the parameters in the above in standards [9] or technical data sheets machines. One of the contemporary challenges in the field of manufacturing systems design is to define the optimal level of their flexibility from the realized manufacturing tasks point of view [3]. The diversity of operating environments in which work feed mixers, created the demand for test and research apparatus and simulation methods enabling the reconstruction of the process in a way resembling real life operation conditions.

Experimental work published so far has focused on operating conditions such as rotation rate, mixer inclination angle, and flow rate [12]. The operation efficiency depended on friction conditions, collisions, cutting, and the machinery design features [1]. While several types of continuous mixers have been built, and many more can easily be conceived, only a few geometric designs have been examined in the literature [12]. Therefore the study of the effects of the design and technological parameters on mix quality is an urgent task.
The mixing process is essential for manufacturing animal feed, and due to the increased use of low-inclusion ingredients, its efficiency becomes even more important, as well as the methods to evaluate this efficiency [13]. When different ingredients are combined to supply a complete animal feed, manufacturers must be able to guarantee that each animal receives the same amount of nutrients and additives in adequate concentrations to meet growth, production, and health requirements [8]. With the increased use of low-inclusion ingredients, such as vitamins, micro-minerals, amino acids and other feed additives in animal nutrition, efficient mixing processes become even more necessary [5]. Feed cost accounts for up to $65 \%$ of the production cost of chicken meat and eggs, and therefore attracts attention as a major opportunity to lower the product cost and increase profits [15]. That is why the process costs of producing dry compound feedstuffs must be kept as low as possible, while complying with quality requirements [2]. The feeds are defined according to certain specifications with regard to nutritive composition based on specified descriptions for nutritional, hygienic and physical quality [17].

One way to increase the livestock production efficiency is to give high-quality complete feeds to livestock animals. When doing this, the best way an agricultural enterprise can provide itself with such feeds in accordance with its needs is if it manufactures its own mixed feed. Cereals are very common ingredients in the food and feed production chain [6]. 
The final operation in the preparation of mixed feed is the mixing of the components in a mixer. It is important in terms of the zootechnics not only to add the components into the feed mix in the correct proportions as provided by the diet, but also to achieve their uniform distribution throughout the mix. The homogeneity of the mix ensures the same nutritional value of the feed in all its portions [20].

\section{Maintenance problems of a horizontal ribbon mixer}

The operation of the horizontal ribbon mixer is based on the principle of mechanical fluidization of the mixed product. The special shape, position and rotation speed of the mixing tools generates centrifugal rotation, what allows the three-dimensional movement of material and its connection with the other components. Components of different particle size and bulk density will be well very finely homogenised and mixed in the shortest possible time.

Mixers of this type are used for mixing dry powders, granules or short fibers and for moistening, balling and granulation of the same materials or for mixing liquids and pastes with low viscosity. During operation they are exposed to a number of factors affecting their correct operation. These devices operate in varying load conditions and mixed delivery, particularly in animal production. Depending on the operating environment there can be identified the following operational problems:

- damage to the bearings on the shaft,

- damage to the drive unit,

- wear of working components of the mixer,

- wear of mixing tools,

- damage to shaft seals,

- abrasive wear of the operating chamber,

- maintenance for the unit to be clean,

- providing sanitary conditions.

The operation of the mixer in variable operating conditions is a difficult issue for the proper delivery of the material and the degree of difficulty depends on the nature of the variability of loads. This problem is particularly significant in the case of composition of compound feed and their delivery in good time for animals. To assess the value of the operating conditions is used a number of approaches, due to the fact that in practice there are different circumstances allowing (or not) the application of certain methods. The variable values of the loads and shock loads, and vibrations affect the shortening of the life of components of machines and equipment used in the production in the animal farms.

\section{Study goals and objectives}

A majority of the existing continuous mixing work examines the effect of the convective system and rotation rate on the mixing behaviour and residence time [12]. The goal and objective of the studies is to improve the process of preparing mixed feed in a horizontal ribbon mixer to make it comply with the zootechnical requirements, to improve the quality of the finished product, and to reduce the power consumption of the process.

\subsection{Techniques}

The experimental studies were carried out in the livestock farming mechanisation laboratory with the use of a PC, measuring and control devices and instruments as per GOST 15.101-98.

The novelty of the complete feed production process is covered by patent No. 2563689 of the Russian Federation, and the design and technological parameters of the mixer are covered by patent No. 2488434 of the Russian Federation [10, 11].
A mix of barley (80\%) and rice (20\%), specific gravity $0.742 \mathrm{t} / \mathrm{m}^{3}$, was used as a base mix in the experiments, and peas of specific gravity $0.812 \mathrm{t} / \mathrm{m}^{3}$ were used as a reference component.
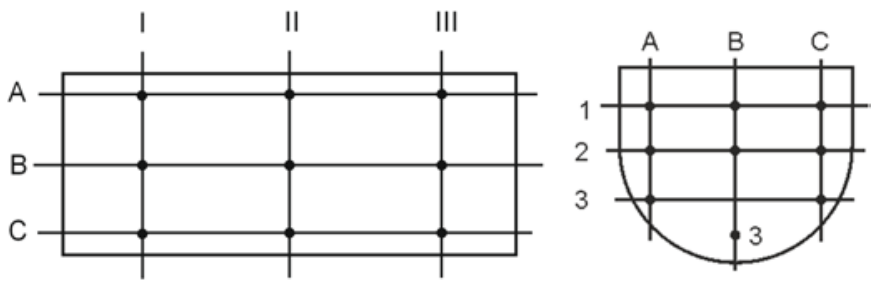

Fig. 1. Scheme of sampling from the mixer: a) horizontal plane; b) vertical plane

Figure 1 shows the scheme of sampling from a horizontal ribbon mixer. Sampling was performed in accordance with GOST R ISO 6497-2011 [4].

It has been experimentally established that if any component is distributed uniformly in the mix, the other components are distributed uniformly as well. We can estimate the homogeneity of a multicomponent mix on the basis of the uniform distribution of the 1 or 2 main components in it.

The main qualitative criterion for the efficiency of any mixing device is the homogeneity of the final product. A mix is considered to be homogeneous if the content of components in any part of its volume corresponds to the mix composition prescribed.

The mixing efficiency is determined on the basis of the statistical characteristics of the mix. This characteristic is the uniformity coefficient of the distribution of the main components in the mix [14]:

$$
V_{c}=\left(1-\frac{\sqrt{\frac{\sum\left(x_{i}-\bar{x}\right)^{2}}{n-1}}}{\bar{x}}\right) \cdot 100 \%,
$$

where: $x_{i}$-is the current value of the observed quantity,

$\bar{x}$ - is the arithmetic mean of the observed quantity,

$n-$ is the number of samples.

The mixer operating time is determined from the formula:

$$
t_{p}=t_{Z}+t_{\mathrm{CM}}+t_{\mathrm{B}}
$$

where: $t_{\mathrm{Z}} \quad-$ is the mixer loading time in min.,

$t_{\mathrm{CM}}$ - is the component mixing time in min.,

$t_{\mathrm{B}} \quad-$ is the finished product discharge time in min.

Mixer capacity $Q$, in $\mathrm{t} / \mathrm{h}$, is determined from the formula:

$$
Q=\frac{m_{\mathrm{O}}+m_{\mathrm{K}}}{t_{p}} \cdot 60,
$$

where: $m_{\mathrm{o}}-$ is the mass of the base mix, $\mathrm{t}$,

$m_{\mathrm{K}}-$ is the mass of the reference component, $\mathrm{t}$.

The power W (in watts) supplied for the experiment is determined from the formula:

$$
W=\frac{3 \cdot U_{\Phi} \cdot I \cdot \cos \varphi}{60} \cdot t_{\mathrm{CM}}
$$

where: $U_{\Phi^{-}}$is the phase voltage, $\mathrm{V}$,

$I-$ is the current measured with ammeter, in amperes, $\cos \varphi-$ is the power coefficient $=0.85$. 
The specific energy consumption, in $\mathrm{kWh} / \mathrm{t}$ is determined from the formula:

$$
q=\frac{3 \cdot U_{\Phi} \cdot I \cdot \cos \varphi}{1000 \cdot Q} .
$$

\section{Research results and discussions}

To determine the required mixing time for the components, singlefactor experiments were carried out which showed the dependence of the uniformity coefficient on the mixing time (Figure 2).

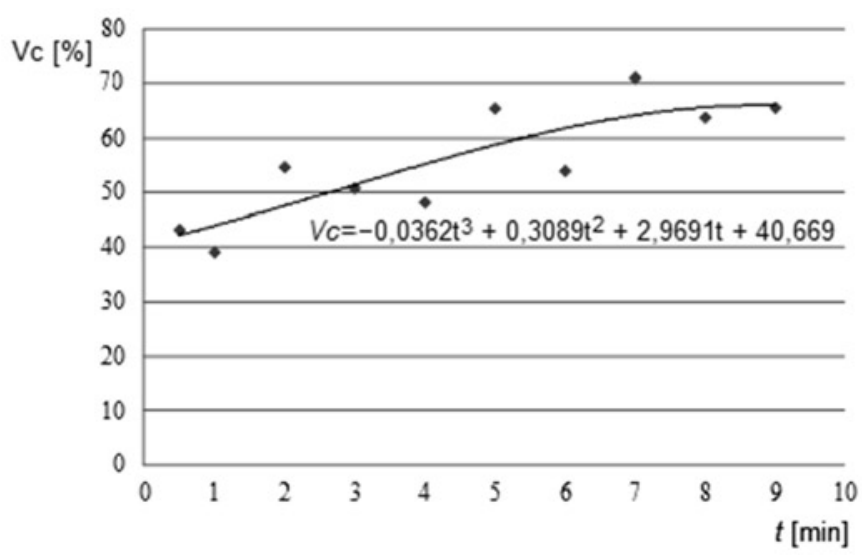

Fig. 2. Relationship between the mix uniformity coefficient and mixing time

An analysis of Figure 2 demonstrates that the best mix uniformity coefficient is achieved with a mixer operating time of 6-8 minutes. On this basis, the mixing time interval will be $4-8$ minutes in future studies.

Following the single-factor experiments, research was carried out using multi-factor experiment planning techniques to establish the optimal design parameters and a more complete study of the working process. The factors indicated below were chosen as the factors to be studied, based on the single-factor experiments:

$\mathrm{x}_{1}$ - quantity of the main component,

$\mathrm{x}_{2}$ - quantity of the reference component,

$\mathrm{x}_{3}$ - mixing time.

The indices indicated below were chosen as the optimisation criteria:

$\mathrm{y}_{1}-$ mix uniformity coefficient $\mathrm{V}_{\mathrm{c}}(\%)$,

$\mathrm{y}_{2}$ - power $\mathrm{W}$ supplied for experiment in watts,

$\mathrm{y}_{3}$ - capacity $\mathrm{Q}$ in $\mathrm{t} / \mathrm{h}$,

$\mathrm{y}_{4}-$ specific energy consumption in $\mathrm{kWh} / \mathrm{t}$.

The matrix of the Box-Behnken plan was used in the experiments (Table 1). The multi-factor experiment that was carried out let us obtain approximate mathematical models of the process which link together all the factors taken into account. From the experimental studies we can determine the numerical values of the coefficients of the equations of the mathematical models, the magnitude of which let us judge the extent of influence of the relevant factors.

The multi-factorial experiment carried out enabled approximate mathematical models for the process to be obtained which link together all the factors taken into account. From the experimental studies we can determine the numerical values of the coefficients in the equations in the mathematical models, the magnitude of which let us judge the significance of the relevant factors. The experimental results were processed on a computer and the following mathematical models were obtained (insignificant factors excluded):
Table 1. Matrix of Box-Behnken plan, intervals and variation in the levels of factors

\begin{tabular}{|c|c|c|c|}
\hline \multirow{3}{*}{ Parameters } & \multicolumn{3}{|c|}{ Factors } \\
\hline & $\begin{array}{l}\text { Quantity of } \\
\text { base mix }\end{array}$ & $\begin{array}{l}\text { Quantity of the } \\
\text { reference com- } \\
\text { ponent }\end{array}$ & Mixing time \\
\hline & $x_{1}$ & $x_{2}$ & $x_{3}$ \\
\hline High level (+) & $900 \mathrm{~kg}$ & $150 \mathrm{~kg}$ & 8 minutes \\
\hline Basic level (0) & $750 \mathrm{~kg}$ & $100 \mathrm{~kg}$ & 6 minutes \\
\hline Low level (-) & $600 \mathrm{~kg}$ & $50 \mathrm{~kg}$ & 4 minutes \\
\hline
\end{tabular}

$\mathrm{y}_{1}=79.76-11.87 \cdot x_{1}-2.42 \cdot x_{3}-8.08 \cdot x_{1}^{2}+2.12 \cdot x_{1} \cdot x_{3}-2.14 \cdot x_{3}^{2}$

$\mathrm{y}_{2}=885.22-53.71 \cdot x_{1}+30.79 \cdot x_{2}+300.88 \cdot x_{3}+18.91 \cdot x_{1}^{2}-6.12 \cdot x_{1} \cdot x_{2}+21.17 \cdot x_{1} \cdot x_{3}+13.70 \cdot x_{2} \cdot x_{3}$

$\mathrm{y}_{3}=5.1+0.91 \cdot x_{1}+0.30 \cdot x_{2}-1.06 \cdot x_{3}-0.18 \cdot x_{1} \cdot x_{3}-0.06 \cdot x_{2} \cdot x_{3}+0.2125 \cdot x_{3}{ }^{2}$

$\mathrm{y}_{4}=1.732-0.213 \cdot x_{1}-0.045 \cdot x_{2}+0.358 \cdot x_{3}+0.078 \cdot x_{1}^{2}-0.037 \cdot x_{1} \cdot x_{3}++0.005 \cdot x_{2}^{2}$

Analysis of the mathematical models (6-9) obtained on the basis of the significance of the coefficients in the regression equations leads to the conclusion that the amount of the reference component in the mix $\left(x_{2}\right)$ has only a slight effect on the optimisation criteria considered. The main factor affecting the mix uniformity coefficient $v_{\mathrm{c}}$ is the quantity of base mix in the mixer $\left(x_{l}\right)$. The power supplied for experiment $\mathrm{W}$, capacity $\mathrm{Q}$, and specific energy consumption $\mathrm{q}$ are mostly affected by the product mixing time $\left(x_{3}\right)$. a)

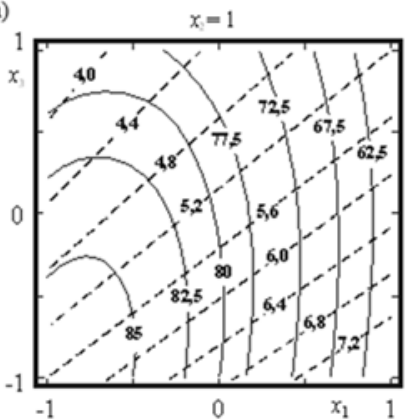

c)

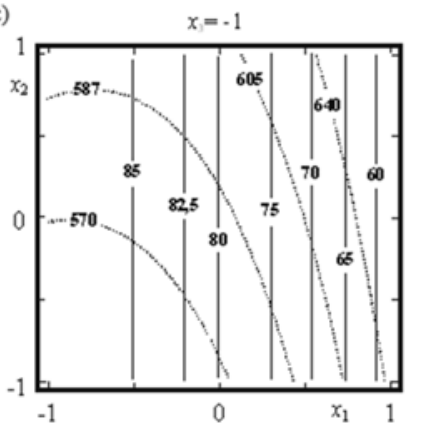

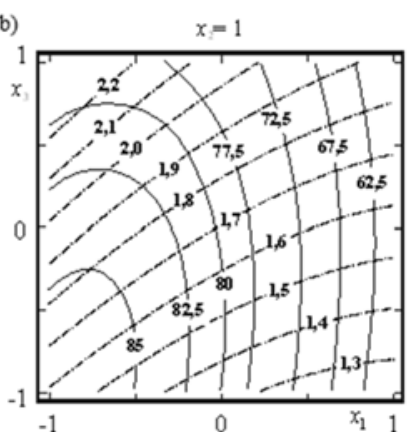

d)

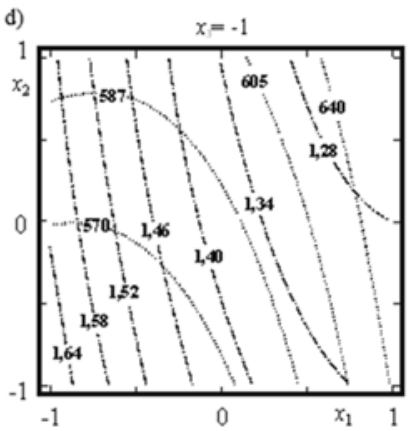

Fig. 3. Two-dimensional cross-sections of the response surface, characterising the influence of the weight of base mix $\left(x_{1}\right)$, weight of reference component $\left(x_{2}\right)$, and mixing time on the: a) finished product uniformity coefficient $V_{c}\left(--y_{1}\right)$, mixer capacity $Q\left(----y_{3}\right)$; b) finished product uniformity coefficient $V_{c}\left(--y_{1}\right)$, specific energy consumption $q\left(\ldots+\cdot-\cdot \cdot-\cdot-y_{4}\right)$; c) finished product uniformity coefficient $V_{c}\left(--y_{1}\right)$, power supplied for the experiment $W\left(\right.$.........................- $\left.\left.-y_{3}\right), d\right)$ power supplied for the experiment $W\left(\cdot \cdots \cdots \cdots \cdots \cdots \cdots \cdots \cdots \cdots \cdots \cdot-y_{3}\right)$, specific energy consumption $q\left(-\cdot \cdot \cdot \cdot \cdot \cdot \cdot \cdot \cdot-y_{4}\right)$ 
Based on the analysis of the mathematical models (6-9) and the two-dimensional cross-sections of the response surface (Fig. 3), the following may be concluded:

As illustrated in Figure 3a), if the amount of base mix $\left(x_{1}\right)$ decreases from 900 to $650 \mathrm{~kg}$, and mixing time $\left(x_{3}\right)$ decreases from 8 to 4 minutes, with a quantity of reference component of $150 \mathrm{~kg}$, the mix uniformity $\mathrm{V}_{\mathrm{c}}$ increases from $62 \%$ to $86.1 \%$, and the mixer capacity $\mathrm{Q}$ decreases from $7.2 \mathrm{t} / \mathrm{h}$ to $5.6 \mathrm{t} / \mathrm{h}$. The maximum uniformity coefficient $\mathrm{V}_{\mathrm{c}}=86.1$ of the finished product is achieved with a quantity of base mix $x_{1}=620 \mathrm{~kg}$, reference component in the mix $x_{2}=146 \mathrm{~kg}$, and mixing time $x_{3}=4$ minutes, in which case the capacity is $\mathrm{Q}=5.6 \mathrm{t} / \mathrm{h}$.

As illustrated in Figure $3 \mathrm{~b}$ ), if the amount of base mix $\left(x_{1}\right)$ decreases from 900 to $650 \mathrm{~kg}$, and mixing time $\left(x_{3}\right)$ from 8 to 4 minutes, with the reference component content $150 \mathrm{~kg}$, the mix uniformity $\mathrm{V}_{\mathrm{c}}$ increases from $62 \%$ to $86.1 \%$, and specific energy consumption $\mathrm{q}$ decreases from 1.9 to $1.6 \mathrm{kWh} / \mathrm{t}$. With a maximum finished product uniformity coefficient $v_{\mathrm{c}}=86.1 \%$, the specific energy consumption $\mathrm{q}=1.6 \mathrm{kWh} / \mathrm{t}$.

Basing on the analysis of two-dimensional sections of the response surface (Figure 3c), the decrease in the amount of base mix $\left(x_{1}\right)$ from 900 to $650 \mathrm{~kg}$, and in the amount of reference component $\left(x_{2}\right)$ from 150 to $50 \mathrm{~kg}$ with a mixing time 4 leads to a decrease in the power supplied to the experiment $\mathrm{W}$ from $640 \mathrm{kWh} / \mathrm{t}$ to $547.5 \mathrm{kWh} / \mathrm{t}$, and an increase in the mix uniformity $v_{c}$ from $60 \%$ to $86.1 \%$.

As illustrated in Figure $3 \mathrm{~d}$ ), an increase in the weight of the base $\operatorname{mix}\left(x_{1}\right)$ from 650 to $900 \mathrm{~kg}$, with a mixing time 4 minutes, and reference component weight $50 \mathrm{~kg}$, leads to an increase in the power $\mathrm{W}$ supplied for the experiment from $547.5 \mathrm{kWh} / \mathrm{t}$ to $640 \mathrm{kWh} / \mathrm{t}$, and a decrease in the specific energy consumption $\mathrm{q}$ from $1.64 \mathrm{kWh} / \mathrm{t}$ to $1.24 \mathrm{kWh} / \mathrm{t}$. The increase in the content of the reference component in the mix $\left(x_{2}\right)$ from 50 to $150 \mathrm{~kg}$, with a weight of base mix of $600 \mathrm{~kg}$ and mixing time of 4 minutes, leads to a decrease in the specific energy consumption q from $1.64 \mathrm{kWh} / \mathrm{t}$ to $1.58 \mathrm{kWh} / \mathrm{t}$. Even though the increase in the weight of base mix leads to an increase in the power supplied to the experiment, the specific energy consumption decreas- es due to the fact that the value of mixer capacity is greater than the variation value of the power supplied for the experiment.

\section{Conclusion}

Summarizing, it must be remembered that while identifying the mathematical model of the horizontal ribbon mixer the mathematical model describes the actual fodder mixer only in an approximate way. Furthermore, it must be added that the conditions in which the identification of the solution model is carried out may be materially different from the actual operation conditions of the blender [18]. The mixing process is highly complicated with a number of affecting parameters, such as the particle properties, the structure and performance of the mixer, the mixing process parameters and the particle feeding order [19].

Experimental studies have shown that mixing time have a clearly influence on the quantity of mixing component, mix uniformity coefficient, capacity and specific energy consumption. According to the experimental results, the maximum product uniformity coefficient $V_{c}=86.1 \%$ is achieved with $620 \mathrm{~kg}$ of the base mix, $146 \mathrm{~kg}$ of the reference component in the mix, mixing time 4 minutes, and a mixer capacity $\mathrm{Q}=5.75 \mathrm{t} / \mathrm{h}$, with a specific energy consumption $\mathrm{q}=1.55 \mathrm{~kW} * \mathrm{~h} / \mathrm{t}$.

In the future work in continuous mixing will further increase the number of parameters examined in the analysis and determine the most significant parameters on its operational. The findings in this study can be the indications to the actual industrial production of feed. Above mentioned problems justify the need to develop new and improve existing solutions of lines for preparation and feeding, corresponding to the current criteria in terms of saving energy and resources, as well as fuller compliance of zootechnical requirements in the technological processes [7].

\section{References}

1. Flizikowski J, Sadkiewicz J, Tomporowski A. Functional characteristics of a six-roller mill for grainy or particle materials used in chemical and food industries. Przemysl Chemiczny 2015; 94(1): 69-75.

2. Fürll C, Hoffmann T. Flow properties of components for dry compound feed. Powder Technology 2013; 235: 838-841, http://dx.doi. org/10.1016/j.powtec.2012.11.019.

3. Gola A, Świć A. Computer-aided machine tool selection for focused flexibility manufacturing systems using economical criteria. Actual Problems of Economics 2011; 124: 383-389.

4. GOST R ISO 6497-2011 - Animal feeding stuffs. Sampling. Standard published on 1.1. 2013; 19.

5. Groesbeck C N, Goodband R D, Tokach M D, Dritz S S, Nelssen J L, DeRouchey J M. Diet mixing time affects nursery pig performance. Journal of Animal Science 2007; 85: 1793-1798, http://dx.doi.org/10.2527/jas.2007-0019.

6. Hernandez M, Esteve T, Pla M. Real-time polymerase chain reaction based assays for quantitative detection of barley, rice, sunflower, and wheat. Journal of Agricultural and Food Chemistry 2005; 53: 7003-7009, http://dx.doi.org/10.1021/jf050797j.

7. Marczuk A, Sysuev V A, Aleškin V A, Savinyh P A, Misztal W, Baran S. Podejście systemowe w badaniach maszyn do przygotowania pasz. Lublin: Uniwersytet Przyrodniczy w Lublinie, 2013.

8. McCoy R A, Behnke K C, Hancock J D, McEllhiney R R. Effect of mixing uniformity on broiler chick performance. Poultry Science 1994; 73: 443-451, http://dx.doi.org/10.3382/ps.0730443.

9. Mizak W, Mazurkiewicz A, Smolik J, Zbrowski A. Problems with abrasive dosing in erosive wear process modelling. Eksploatacja i Niezawodnosc - Maintenance and Reliability 2014; 16(4): 559-564.

10. Pat. 2488434 Russian Federation, MPK7 B 01 F 7/8. Mixer/Savinykh P A, Turubanov N V, Romanyuk V, Kiselev A S, Chernyatyev N A. Applicant and patentee - State Scientific Institution "N.V. Rudnitsky North-West Scientific Research Institute of Agriculture" (Russian Federation) and the Institute of Technology and Natural Sciences (Poland). No.2012104920/05, appl. 02/13/2012; publ. 07/27/2013, bull. No. 21.- 5 p: ill.

11. Pat. 2563689 Russian Federation, C1 MPKA 23N 17/00 (2006/01). Mixed feed preparation technique / Sysuev V A, Savinykh PA, Turubanov N V, Chernyatyev N A, Kazakov V A, Saitov V E. Applicant and patentee - State Scientific Institution "N.V, Rudnitsky North-West Scientific Research Institute of Agriculture" of the Russian Academy of Agricultural Sciences (RU); No. 2014113057/13; appl. 04/03/2014; publ. 09/20/2015, bull. No. 26. - 7 p.: ill.

12. Portillo P M, Ierapetritou M G, Muzzio F J. Effects of rotation rate, mixing angle, and cohesion in two continuous powder mixers - A statistical approach. Powder Technology 2009; 194: 217-227, http://dx.doi.org/10.1016/j.powtec.2009.04.010. 
13. Rocha A G, Montanhini R N, Dilkin P, Tamiosso C D, Mallmann C A. Comparison of different indicators for the evaluation of feed mixing efficiency. Animal Feed Science and Technology 2015; 209: 249-256, http://dx.doi.org/10.1016/j.anifeedsci.2015.09.005.

14. Savinykh P A, Turubanov N V, Ustyugov S Y, Lodygin D G. Research results for mixing in the vertical screw mixer of a small-sized feed unit. Bulletin of the All-Russian Scientific Research Institute of Animal Husbandry Mechanisation 2005; 15(3): 75-79.

15. Singh Y, Amerah A M, Ravindran V. Whole grain feeding: Methodologies and effects on performance, digestive tract development and nutrient utilisation of poultry. Animal Feed Science and Technology 2014; 190: 1-18, http://dx.doi.org/10.1016/j.anifeedsci.2014.01.010.

16. Świć A, Wołos D, Litak G. Method of control of machining accuracy of low-rigidity elastic-deformable shafts. Latin American Journal of Solids and Structures 2014; 2(11): 260-278.

17. Thomas M, vun der Poe1 A F B. Physical quality of pelleted animal feed 1. Criteria for pellet quality. Animal Feed Science and Technology 1996; 61: 89-112, http://dx.doi.org/10.1016/0377-8401(96)00949-2.

18. Tomporowski A, Opielak M. Structural features versus multi-hole grinding efficiency. Eksploatacja i Niezawodnosc - Maintenance and Reliability 2012; 14(3): 222-227.

19. Xiao X, Tan Y, Zhang H, Jiang S, Wang J, Deng R, Cao G, Wu B. Numerical investigation on the effect of the particle feeding order on the degree of mixing using DEM. Procedia Engineering 2015; 102: 1850-1856, http://dx.doi.org/10.1016/j.proeng.2015.01.323.

20. http://seveks.ru/Smehivanie_kombikorma.htm.

\section{Andrzej MARCZUK \\ Jacek CABAN}

Department of Transporting and Agricultural Machinery

University of Life Sciences in Lublin

ul. Głęboka, 20-612 Lublin, Poland

\section{Petr SAVINYKH}

Nikolay TURUBANOV

Dmitry ZYRYANOV

Zone Scientific and Research Institute of North East Agriculture in Russia

The Russian Academy of Agricultural Sciences

164/43 Lenin Str., 610017 Kirov, Russia

E-mails: andrzej.marczuk@up.lublin.pl, jacek.caban@up.lublin.pl, peter.savinyh@mail.ru,nikolaytu@mfil.ru,dimonzyryanov@vfil.ru 